\title{
Overview of olestra: A new fat substitute
}

Richard Hunt MD, Nora L Zorich MD PhD, Alan BR Thomson MD PhD FRCPC FACG

R Hunt, NL Zorich, ABR Thomson. Overview of olestra: A new fat substitute. Can J Gastroenterol 1998;12(3): 193-197. Olestra is a mixture of hexa-, hepta- and octa-esters formed from the reaction of sucrase and long chain fatty acids isolated from edible oils. Olestra has properties similar to those of traditional triglycerides but is not hydrolyzed by pancreatic lipases and, therefore, serves as a noncaloric replacement for fats in the diet. The safety of olestra has been established in over 100 studies in seven different species of animals, with confirmatory safety data coming from approximately 75 human studies; consumption of olestra at levels typical for savoury snacks does not result in reports of gastrointestinal problems in humans. This is consistent with the results of studies of the physiological and morphological effects of olestra in animals and in humans. It is anticipated that olestra will be available in Canada in the near future. Patients will soon be asking their physicians about its use. This article provides an overview of olestra.

Key Words: Fats, Lipids, Nutrition, Olestra, Savoury snacks

\section{Survol de l'olestra : un nouveau substitut du gras}

RÉSUMÉ : L'olestra est un mélange d'hexa-, d'hepta- et d'octa-esters formés à partir de la réaction de la sucrase et des acides gras en chaînes longues isolés dans les huiles comestibles. L'olestra possède des propriétés semblables à celles des triglycérides classiques, mais n'est pas hydrolysée par les lipases pancréatiques, et de ce fait, peut agir à titre de substitut non calorique des graisses dans l'alimentation. L'innocuité de l'olestra a été confirmée dans plus de 100 études auprès de sept espèces animales différentes, avec données d'innocuité à l'appui provenant d'environ 75 études chez l'être humain. La consommation d'olestra à des taux typiques pour des goûters savoureux n'entraîne aucun problème digestif chez l'être humain. Cela concorde avec les résultats d'études sur les effets physiologiques et morphologiques de l'olestra chez l'animal et chez l'être humain. On prévoit que l'olestra sera offert au Canada dans un proche avenir. Nos patients s'informeront bientôt de son utilisation auprès de leurs médecins. Cet article veut dresser un tableau d'ensemble de l'olestra.
$\mathrm{O}$ estra is a new food ingredient developed by Proctor $\&$ Gamble to be sold under the brand name Olean. Olestra provides the flavour and desirable texture of fats and oil to foods without adding any fat or calories. Because of its thermal stability, olestra can be used to replace fat in a variety of foods, including baked and fried foods. Currently marketed fat replacers such as carbohydrate-based gums and emulsifiers, and microarticulated proteins are not heat stable. Thus, these replacers have limited use in baked products and cannot be used to prepare fried foods (1).

In January 1996, the United States Food and Drug Ad- ministration (FDA) approved the use of olestra to replace $100 \%$ of the vegetable oil used in the preparation of savoury snacks (2). Savoury snacks include flavoured and unflavoured chips such as potato chips, corn chips and tortilla chips, as well as snacks such as cheese puffs and curls, and crackers (eg, soda crackers). It is anticipated that olestra will be available in Canada in the near future.

Olestra is made from two common food ingredients, sucrose and vegetable oil. Olestra's structure is analogous to that of a triglyceride, with sucrose instead of glycerol as the core, and six to eight fatty acid side chains rather than three.

McMaster University, Hamilton, Ontario; Procter $\mathcal{E}$ Gamble Company, Cincinnati, Ohio, USA; Division of Gastroenterology, University of Alberta, Edmonton, Alberta

Correspondence: $\operatorname{Dr}$ ABR Thomson, Department of Medicine, Division of Gastroenterology, University of Alberta, Edmonton, Alberta

T6G 2C2. Telephone 403-492-6490, fax 403-492-7964, e-mail alan.thomson@ualberta.ca

Received for publication September 2, 1997. Accepted January 2, 1998 
The fatty acids can be derived from any vegetable oil. Because of the large size of the olestra molecule it is not absorbed intact nor is it broken down by digestive enzymes. Therefore, it adds no calories, fat or sugar to the diet $(1,3)$.

The physical properties and heat stability of olestra are comparable with those of conventional fats and oils. As with triglycerides, the physical properties of olestra are determined by the properties of the fatty acid side chains. For example, olestra made with predominately polyunsaturated fatty acids is a clear liquid resembling typical vegetable oils. In contrast, olestra made with more saturated fatty acids is an opaque solid, resembling a higher melting point solid fat.

\section{ROLE OF OLESTRA IN THE DIET}

An excess of fat in the diet is associated with an increased risk of coronary artery disease, stroke, certain kinds of cancers and obesity. Consistent with these observations, leading health authorities and health professionals recommend that the diet provide no more than about $30 \%$ of calories from fat. Despite these recommendations, many North Americans continue to eat more than the recommended level of fat. In addition, the prevalence of obesity is increasing in North America (4). Olestra will not replace the need for balance, moderation and variety in achieving a healthy diet, but it does provide one tool to help people meet the recommended dietary goals.

Fat and calorie reduction: Snack intake continues to rise despite consumer awareness of fat reduction guidelines. Because snacks are typically high in fat and calories, they present a logical target for efforts to reduce fat intake. Sensory studies have shown that olestra can reduce the fat content of snack foods without affecting taste. The reduction in fat intake accomplished by the substitution of olestra snacks for full-fat snacks can be a positive step towards a person's improved health and weight control. For example, a $1 \mathrm{oz}(30 \mathrm{~g})$ bag of potato chips made with vegetable oil contains about $10 \mathrm{~g}$ fat and 150 calories. This same bag of potato chips made with olestra contains no fat and only about 70 calories. A reduction in fat intake of $10 \mathrm{~g}$ per day, which could be accomplished by substituting one bag of potato chips made with olestra for regular potato chips per day, would save the same number of calories over a year as those in $3.6 \mathrm{~kg}$ of fat.

Numerous studies have confirmed that olestra can help people reduce the percentage of calories from fat in their diets, even among individuals who do not need to reduce total caloric intake. For example, studies of the impact of olestra on the diets of lean men and children have shown that, while total caloric intake is unchanged when olestra is substituted for fat in the diet, the percentage of calories that come from fat is decreased and the percentage derived from carbohydrate is increased. In two studies, lean male subjects ate a test breakfast in which olestra replaced 0,20 or $36 \mathrm{~g}$ of fat and were then allowed to eat whatever they wanted over the next $24 \mathrm{~h}$. The results from the two studies were essentially the same - olestra substitution significantly reduced the percentage of calories from fat ( $41 \%$ to $35 \%)$ and increased the percentage of calories from carbohydrates $(40 \%$ to $45 \%$ ). Thus, there does not appear to be a 'fat specific' appetite that might render fat replacement ineffective in reducing fat intake. Total daily energy intake was not changed - an indication that caloric regulation was not affected by olestra (5).

In a study of similar design in two- to five-year-old children, $13.7 \mathrm{~g}$ of fat in the first three meals of the day was replaced with olestra, and the food intake of the children was monitored for two days. Olestra substitution significantly reduced the percentage of calories from fat (38.7\% to 36.4\%) and increased the percentage of calories from carbohydrate (51.5\% to $53.3 \%)$. Importantly, olestra did not reduce total caloric intake nor did it put the children at risk of insufficient intake of essential nutrients. These findings show that substituting olestra for fat in the diets of individuals who do not need to reduce their energy intake provides a fat reduction benefit (6).

Three longer term studies showed a reduction in the intake of both fat and calories following the consumption of olestra. A 14-day study in obese and nonobese men and women, and a 14-day study in young males, showed that fat intake and caloric intake were reduced (7). An 18-day study in obese dieters also showed a reduction in both caloric and fat intake, indicating that olestra may have a role to play in weight reduction (8).

In another study, people who normally eat potato chips as part of their diet consumed chips made with either olestra or vegetable oil as a midafternoon snack in addition to their usual foods (9). The study population included males, females, obese and normal-weight individuals, some people who self-restrained their food intake and some who did not. In one phase of the study the subjects knew when they were eating olestra chips and when they were eating full-fat chips. In another phase, they were not aware of the kind of potato chips they were eating. Most subjects ate the same amount of potato chips, regardless of whether they knew they were eating full-fat or olestra potato chips. One group, the selfrestrained eaters, ate an average of $10 \mathrm{~g}$ more olestra potato chips when they knew what they were eating than when they did not. All groups consumed fewer calories from fat when they ate olestra potato chips, even those individuals who ate more olestra potato chips.

These studies show that olestra can help people take small steps towards improving their diets by expanding their options for good tasting, lower fat foods. These findings also provide encouraging evidence that olestra can help people move towards the dietary goal of reducing their fat intake.

Effect of olestra on dietary components: The potential effects of olestra consumption on the absorption of essential fat soluble and water soluble dietary components have been investigated extensively in animals and humans. Olestra does not affect the availability of water soluble micronutrients or the absorption and utilization of macronutrients. Olestra can reduce the absorption of fat soluble vitamins $\mathrm{A}, \mathrm{D}, \mathrm{E}$ and $\mathrm{K}$ when snacks containing olestra are consumed at the same time as these nutrients. Although the overall effect of eating snacks with olestra is nutritionally insignificant, because 
consumers are unlikely to consume olestra snacks with all meals on a daily basis, any potential effect has been offset by adding each of the four fat soluble vitamins to olestra foods on a per-gram basis. Thus, the person eating snacks made with olestra will maintain the United States recommended daily intake for each of the fat soluble vitamins. The amounts required to achieve this offset are small. For example, the amount of vitamin A added to one serving of potato chips made with olestra is roughly the amount found in one-third of a serving of fortified breakfast cereal. The nutritional effects of olestra have been assessed extensively, and the results were published recently in the Journal of Nutrition (10).

Cholesterol lowering effects: Studies in animals and humans have shown that olestra decreases the absorption and enhances the excretion of cholesterol. At normal levels of intake, olestra has a modest beneficial effect on lowering total cholesterol and low density lipoprotein cholesterol, while causing no untoward effect on triglycerides, high density lipoprotein cholesterol or apolipoproteins A-I, A-II and B $(11,12)$. Olestra's primary beneficial effect on serum cholesterol, however, comes from reducing the intake of saturated fat.

\section{CONSUMPTION OF OLESTRA FROM SAVOURY SNACKS}

An integral part of assessing the safety of a new food ingredient is knowing how much of the product people will eat. Unlike traditional food additives, which are consumed in very small quantities (usually in the order of a few milligrams per day), a macronutrient additive such as olestra may be consumed in gram quantities each day. Procter \& Gamble has used a method originally developed by the National Academy of Sciences and accepted by the FDA to estimate the likely consumption of olestra from savoury snacks (13). This procedure involved a 14-day menu survey, in which all foods and beverages consumed by 2000 households and 5000 individuals were tracked. The households were nationally representative of geography, size and income, and the survey was run throughout the year to capture seasonal variation in food availability and intake. Portion sizes of food items were determined from the United States Department of Agriculture Nationwide Food Consumption Survey, and the olestra content of typical savoury snacks was measured analytically.

For the general American population, the estimated mean and 90th percentile single-day (acute) intakes of olestra are about $10 \mathrm{~g} /$ day and $18 \mathrm{~g} /$ day, respectively (a $28.4 \mathrm{~g} \mathrm{bag}$ of potato chips contains about $8.4 \mathrm{~g}$ of olestra, corn chips have about $5.5 \mathrm{~g}$ of olestra). The estimated mean and 90th percentile chronic intakes are about $3 \mathrm{~g} /$ day and $7 \mathrm{~g} /$ day, respectively. For children (ages six to 12) and teenagers (ages 13 to 17) the 90th percentile chronic intakes of olestra are about $7 \mathrm{~g} /$ day and $10 \mathrm{~g} /$ day, respectively. Menu census data were also used to estimate the frequency of snack consumption and the frequency with which they are eaten with meals. The average consumer eats snacks about five times in 14 days; the 90th percentile consumer eats them about 10 times in two weeks. Average and 90th percentile eaters consume snacks with $8 \%$ and $18 \%$ of meals, respectively (13).

\section{OLESTRA SAFETY PROGRAM}

Olestra is not absorbed from the gastrointestinal tract. This fact was established in a comprehensive program involving several kinds of testing. First, to determine its disposition and fate if it were to be absorbed, rats were injected intravenously with radiolabelled olestra. The systematically available olestra accumulated in the liver, specifically in the Kupffer cells and later in the parenchymal cells, and was excreted slowly intact in the bile. With the target organ identified, the potential for olestra to be absorbed when dosed orally was determined. A series of studies using highly purified radiolabelled olestra samples was conducted in rats. In addition, the potential effect on absorption of heating under conditions representative of those encountered when olestra is used to prepare savoury snacks was investigated. These studies showed that the maximum absorption of olestra was at the detection limit of the sensitive radiolabel detection method, which was no more than $0.0001 \%$ of the administered dose $(14,15)$.

Small variations in composition of olestra (within the FDA approved specifications, including heating) had no effect on its absorption. Using the same methodology, it was also established that olestra was essentially not absorbed in weanling minipigs (this provides a model of the gastrointestinal tract of young children), or in guinea-pigs in which the integrity of the gastrointestinal tract was compromised (a model that simulates the gastrointestinal tract in people with inflammatory bowel disease). Lifetime rodent feeding studies confirmed that olestra did not accumulate in any tissue, including the liver.

The safety of olestra has been investigated in a large number of short term and long term animal experiments, and has been confirmed in controlled human clinical studies. This program has exceeded the testing typically required for regulatory approval of a food ingredient, both in the number of tests and in the number of species used in the animal toxicology program, as well as by the inclusion of extensive human clinical studies. Safety testing comprised the following six broad areas: absorption of olestra; standard toxicity; olestra's impact on the gastrointestinal tract; olestra's potential effect on nutrient availability; confirmation of olestra's safety in segments of the population with special nutritional needs, such as children, pregnant or lactating women and the elderly; and environmental toxicology. This extended and careful program reflects the fact that macronutrient replacers are consumed in much greater quantities than traditional food additives.

The safety of olestra has been established in over 100 studies in seven different species of animals, with confirmatory safety data coming from approximately 75 human studies. Animal experiments included lifetime studies in rats and mice, and long term studies in dogs. The experiments showed that olestra is not toxic, mutagenic, carcinogenic or teratogenic. It does not affect the animal's growth and development, nor does it affect the morphology and function of the gastrointestinal system, the only organ system that is exposed to olestra. These findings are not surprising, given that 
olestra is not metabolized in the gastrointestinal tract and is not absorbed $(1,3)$.

In comparative studies in which individuals consumed olestra or triglyceride foods at every meal for 56 consecutive days, subjects who received higher levels of olestra reported a greater frequency of gastrointestinal symptoms than subjects who received conventional triglyceride at comparable levels $(16,17)$. These findings account for the presence of a product information label for consumers who may be eating substantial amounts of olestra on a daily basis. However, subjects in these same studies who consumed olestra foods at the 90th percentile of expected chronic consumption (13) did not report significantly more gastrointestinal effects than subjects who consumed conventional triglycerides at comparable levels.

Other studies in humans have demonstrated little to no differences in the frequency of reporting of meaningful gastrointestinal symptoms among subjects who consumed olestra chips or triglyceride chips in single eating occasions or in typical snack eating simulations. In a recent double-blind randomized parallel study, 1092 participants ate as much as they wanted of a $369 \mathrm{~g}$ bag of olestra or triglyceride potato chips at a single eating occasion (18). There was no difference in the frequency of reporting of gastrointestinal symptoms overall or of any individual gastrointestinal symptoms between subjects who consumed olestra potato chips and those who consumed triglyceride potato chips. In placebo controlled studies, olestra was consumed in various foods at daily consumption levels of about $20 \mathrm{~g} /$ day (equivalent to $70.9 \mathrm{~g}$ of olestra potato chips) for 16 weeks by 146 normal, healthy subjects (19) or for four weeks by 41 persons with inflammatory bowel disease (20). In both studies, there were no differences between the placebo and olestra groups in the reporting rates of any gastrointestinal symptoms, including diarrhea or abdominal cramping, except for more reports of minor changes in stool frequency or stool character by subjects with inflammatory bowel disease when they ate foods made with olestra. Importantly, these changes were not

\section{REFERENCES}

1. Bergholz CM. Safety evaluation of olestra, a nonabsorbed fat replacement. Crit Rev Food Sci Nutr 1992;32:141-6.

2. United States Food and Drug Administration (FDA). Food additives permitted for direct addition to food for human consumption: olestra; final rule. Fed Regist 1996;61:3118-73.

3. Lawson KD, Middleton SJ, Hassall CD. Olestra, a nonabsorbed, noncaloric replacement for dietary fat. A review. Drug Metab Rev 1997;29:651-703.

4. The Canadian Heart Health Surveys. Obesity: a risk factor for cardiovascular disease. Can Med Assoc J 1997;157:S1-53.

5. Rolls BJ, Pirraglia PA, Jones MB, Peters JC. Effect of olestra, a nonactive substitute on daily energy and fat intake in lean men. Am J Clin Nutr 1992;56:84-92.

6. Birch LL, Johnson SL, Jones MB, Peters JC. Effects of a nonenergy fat substitute on children's energy and macronutrient intake. Am J Clin Nutr 1993;58:326-33.

7. Bray GA, Sparti A, Windhauser MM, York PA. Effect of two weeks fat replacement by olestra on food intake and energy metabolism. FASEB J 1995;9:2545. (Abst A439)

8. Glueck CJ, Hastings MM, Allen C, et al. Sucrose polyester and covert caloric dilution. Am J Clin Nutr 1982;35:1352-9.

9. Miller DL, Hammer VA, Shide DJ, Peters JC, Rolls BJ. Consumption characterized as diarrhea by inflammatory bowel disease patients (20).

That consumption of olestra does not result in reports of gastrointestinal symptoms under snack eating conditions is consistent with the results of studies of the physiological and morphological effects of olestra in animals and humans. Such studies have demonstrated that olestra does not injure the gastrointestinal mucosa (21-24) or result in malabsorption of carbohydrates, proteins or fats (3). Further, olestra does not significantly alter fecal bile acid excretion (25), result in significant changes in gastrointestinal transit (26) or lead to significant alterations in stool water content $(12,27)$. Olestra is not metabolized by the colonic microflora (27) and does not cause pathological alteration in the colonic microflora $(28,29)$. Olestra is not recognized as fat by the body and does not signal cholecystokinine release (30). This supports the concept that, although olestra works in food like fat, it does not work in the body like fat. Rather, it passes through the body unchanged adding bulk to the stool and softening the stool. It would not be unexpected for consumers to notice this softening effect, particularly if they consumed foods made with olestra on a regular basis.

\section{CONCLUSIONS}

Olestra is a mixture of hexa-, hepta- and octa-esters formed from the reaction of sucrase and long chain fatty acids isolated from edible oils. Olestra has properties similar to those of traditional triglycerides but is not hydrolyzed by pancreatic lipases and, therefore, serves as a noncaloric replacement for dietiary fats. The safety of olestra has been established in over 100 studies in seven different species of animals, with confirmatory safety data coming from approximately 75 human studies; consumption of olestra at levels typical for snacks does not result in reports of gastrointestinal symptoms in humans. This is consistent with the results of studies of the physiological and morphological effects of olestra in animals and humans. It is anticipated that olestra will be available in Canada in the near future.

of fat-free potato chips by obese and restrained males and females. Presented at the Annual Meeting of the Federation of American Societies for Experimental Biology, Atlanta, April 9 to 13, 1995.

10. Assessment of the nutritional effects of olestra. J Nutr 1997;127 (8 Suppl):1539S-728S.

11. Crouse JR, Grundy SM. Effects of sucrose polyester on cholesterol metabolism in man. Metabolism 1979;28:994-1000.

12. Fallat RW, Glueck CJ, Lutmer R, Mattson FH. Short term study of sucrose polyester a nonabsorbable fat-like material as a dietary agent for lowering plasma cholesterol. Am J Clin Nutr 1976;29:1204-15.

13. Webb DR, Harrison GG, Lee MJ, Huang MH. Estimated consumption and eating frequency of olestra from salt snacks using new consensus data. J Nutr 1997;127:1547S-54S.

14. Daher GC, Lawson KD, Tallmadge DH, Vanderploeg P, Miller KW. Disposition of ingested olestra in weanling mini-pig. Food Chem Toxicol 1996;34:683-9.

15. Miller KW, Lawson KD, Tallmadge DH, et al. Disposition of ingested olestra in the Fischer 344 rat. Fundam Appl Toxicol 1995;24:229-37.

16. Schlagheck TG, McEdwards JM, Jones MB, et al. Olestra's effect on vitamins $\mathrm{D}$ and $\mathrm{E}$ in humans can be offset by increasing dietary levels of these vitamins. J Nutr 1997;127:1666S-85S.

17. Schlagheck TG, Riccardi KA, Zorich NL, Torri SA, Dugan LD, Peters 
JC. Olestra dose response on fat-soluble nutrients in humans. J Nutr 1997;127(8 Suppl):1646S-65S.

18. Cheskin L, Miday RK, Zorich NL, Filloon TG. Gastrointestinal symptoms following acute consumption of olestra or regular triglyceride potato chips: a control comparison. JAMA 1998;279:150-2.

19. Koonsvitsky BP, Berry DA, Jones MB, et al. Olestra affects serum concentrations of alpha-tocopherol and carotenoids but not vitamin D or vitamin $\mathrm{K}$ status in free-living subjects. J Nutr 1997;127:1636S-45S.

20. Zorich NL, Jones MB, Kesler JM, Carter SB, Sutton MA, Bayless T. A randomized, double-blind study of the effect of olestra on disease activity in patients with quiescent inflammatory bowel disease. Olestra in IBD Study Group. Am J Med 1997;103:389-99.

21. Miller KW, Wood FE, Stuard SB, Alden CL. A 20-month olestra feeding study in dogs. Food Chem Toxicol 1991;29:427-35.

22. Lafranconi WM, Long PH, Atkinson JE, Knezevich AL, Wooding WL. Chronic toxicity and carcinogenicity of olestra in Swiss DC-1 mice. Food Chem Toxicol 1994;32:789-98.

23. Wood FE, Tierney WJ, Knezevich AL, Bolte HF, Maurer JK, Bruce RD. Chronic toxicity and carcinogenicity studies of olestra in Fischer 344 rats. Food Chem Toxicol 1991;29:223-30.
24. Miller KW, Long PH. A 91-day feeding study in rats with heated olestra-vegetable oil blends. Food Chem Toxicol 1990;28:307-15

25. Glueck CJ, Jandacek RJ, Ravi Subbiah MT, et al. Effect of sucrose polyester on fecal bile acid excretion and composition in normal men. Am J Clin Nutr 1980;33:2177-81.

26. Aggarwal AM, Camilleri M, Phillips SF, Schlagheck TG, Brown ML, Thomforde GM. Olestra, a nondigestible, nonabsorbable fat. Effects on gastrointestinal and colonic transit. Dig Dis Sci 1993;38:1009-14

27. Bergholz CM. Safety evaluation of olestra a nonabsorbable fat replacement derived from fat. In: Finley JW, Robinson SF, Armstrong DH, eds. Food Safety Assessment, ACS Symposium Series 484. Washington: American Chemical Society, 1992:391-9.

28. Nuck BA, Schlagheck TG, Federle TW. Inability of the human fecal microflora to metabolize the nonabsorbable fat substitute, olestra. J lndust Microbiol 1994;13:328-34.

29. Eastwood MA, Allgood GS. The effect of olestra on breath gas production and fecal microbial counts. Eur J Clin Nutr 1995;49:627-39.

30. Siigur U, Norm KE, Allgood GS, Schlagheck T, Midtvedt T. Effect of olestra upon intestinal microecology as reflected by five microflora associated characteristics in man. Microb Ecol Health Dis 1996;9:295-303. 


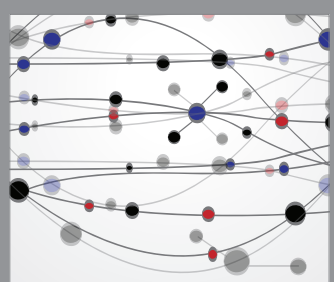

The Scientific World Journal


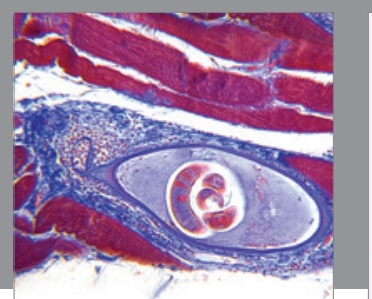

Gastroenterology Research and Practice

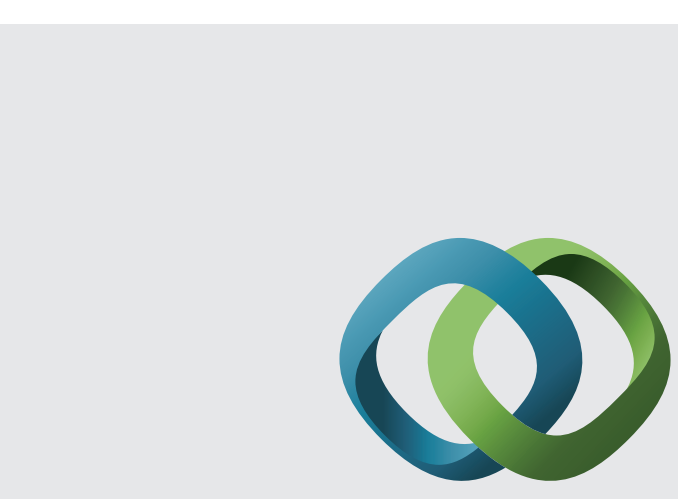

\section{Hindawi}

Submit your manuscripts at

http://www.hindawi.com
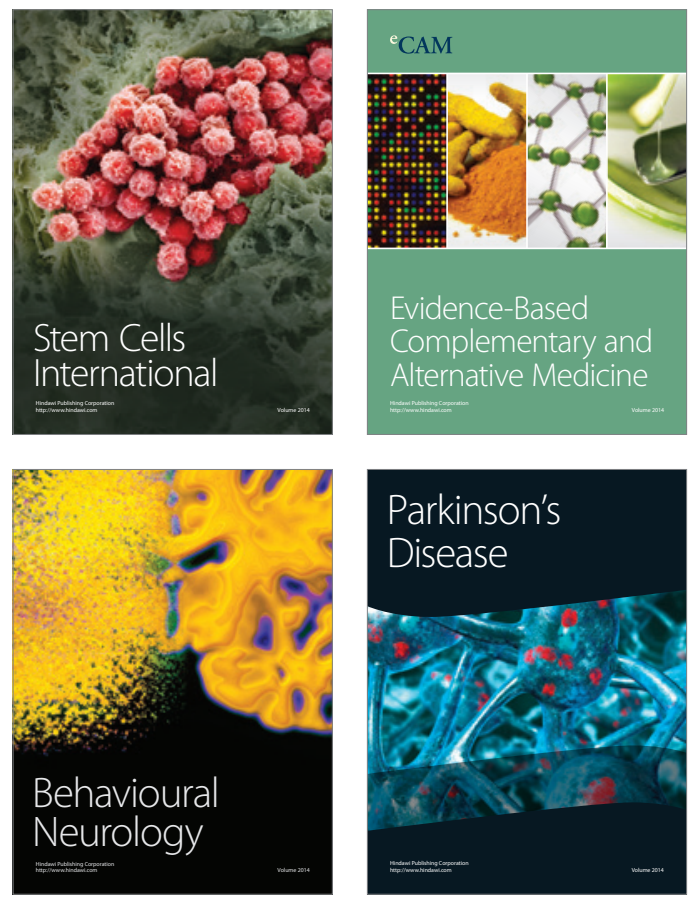


Disease Markers
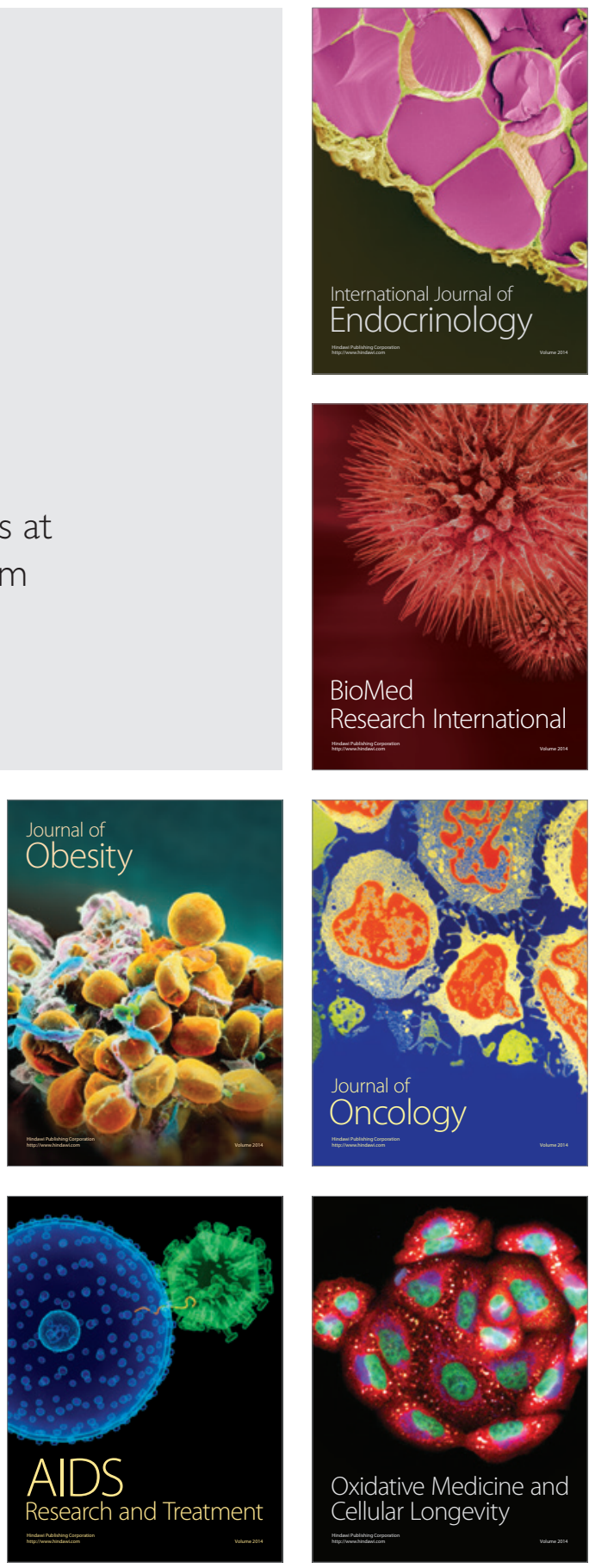